\title{
The Virtual Debt Factory: Towards an Analysis of Debt and Abstraction in the American Credit Crisis
}

\author{
Vincent R. Manzerolle \\ Faculty of Information and Media Studies, University of Western Ontario \\ London, Ontario, Canada \\ vmanzero@uwo.ca
}

Contribution to the tripleC-special issue "Capitalist Crisis, Communication \& Culture", edited by Christian Fuchs, Matthias Schafranek, David Hakken, Marcus Breen

\begin{abstract}
Emanating from the United States, the ongoing global credit crisis has provided important insights into a shady new area of capitalist exploitation: the consumer debt factory. In an effort to speed up and quantifiably increase the circulation of consumer credit to match the consumption needs of post-Fordist accumulation, this industry-comprising financial institutions, consumer database companies, and credit rating agencies-has created a highly detailed body of information to stand-in for the corporeal self. This paper therefore examines this industry's conceptualization of the self as a disembodied mechanism for mass-producing debt, creating a highly volatile informational commodity divorced from all material constraints. In using the credit crisis as a focal point, this paper considers how the far-reaching credit apparatus at the heart of the debt factory gives rise to the fatal abstractions that support, and ultimately undermine, contemporary capitalist economies. By substituting data for flesh, the credit industry has created an antagonism between the material and informational forms of the self, resulting in the construction of a virtual debtors prison. The ensuing analysis will highlight both the exploitative nature of this bifurcation as well as its profound contradictions.
\end{abstract}

Keywords: Credit Industry, Consumption, Crisis, Abstraction, Neoliberalism, Surveillance, Commodification of Debt, Digital Capitalism.

Acknowledgement: A version of this paper was presented at the Rethinking Marxism conference, November 5-8, 2009, University of Massachusetts at Amherst. Many thanks are owed to Dr. Alison Hearn, Trent Cruz, Atle Mikkola Kjosen, and the Triple- $C$ reviewers for helping develop and refine the arguments presented in this paper.

The purpose of this paper is to examine the ongoing credit crisis emanating from the United States from a perspective that highlights the changing mediation between creditors and debtors. In so doing, it describes the mechanisms that have enabled the commodification of debt and the resulting contradictions that have emerged out of post-Fordist accumulation strategies (Harvey, 1990; DyerWitheford, 1999; Virno, 2003; Fisher, 2010), centering on a key antagonism between the virtual and the corporeal. Because these developments have sprung predominantly from capitalist economies, this paper positions itself within the historical materialist analysis offered by Marx (1976) in Capital, which, among other things, examines the creation and reproduction of capitalist social relations dialectically intertwined within the dynamic of technological innovation and the ever expanding accumulation of capital. Using this analytic perspective, my analysis will highlight how the current crisis conjures into being a unique set of necessary abstractions arising from the intersection of neoliberal policies and digital technologies. This paper argues that these abstractions lead to the opposition, indeed antagonism, between the world of flesh and blood and that of the digital, creating an ever-expanding virtual debtors prison. I conclude the paper by suggesting that these developments offer an opportunity to rethink Marx's chapter on primitive accumulation in assessing the long-term implications of the digitally mediated relationship between creditors and debtors. Although this paper does not conclude that primitive accumulation supercedes capitalist accumulation proper, it does forward the thesis that Marx's analysis can be redeployed to understand forms of exploitation that are emergent and unique to the capitalist application of digital technologies. "So-called primitive accumulation" - Marx used the quotations purposefully-conceptually highlights the vital role of social relations in the constitution of capitalism, but also their impermanence, subject to violent reorganizations, including the structural crises endemic to capitalist accumulation itself. 
First, I discuss the relationship between creditors and debtors as an historically important ensemble of relations that is often subject to reorganization, including in our contemporary, and evermore digitally mediated, historical moment; second, I elaborate upon the concept of abstraction as a central component in the reproduction of capitalist social relations under capitalism (private property, wage-labor, to which I add creditor-debtor as a preeminent social mediator under postFordism) and how the 'real abstractions' sprung from the necessity of capitalist accumulation play a central role in reproducing or transforming social relations; third, I sketch a genealogy of the consumer debt commodity in the United States as it emerged in the contemporary era, followed by a section addressing the particular effects of neoliberal policies on the creation of a debt producing and profiting industry; finally, I suggest that the resulting crises, still being experienced across the globe, stem from contradictions inherent in the substitution of data for flesh in the credit apparatus, and thereby providing an alibi for potentially new forms of digital primitive accumulation. ${ }^{1}$

\section{Credit System as Social Mediator}

Credit institutions have played a central role in the political and economic evolution of Western civilization emerging in tandem with the spread of writing as a bureaucratic tool for managing the growth of early metropolitan communities (MacDonald \& Gastmann, 2001). For example, as one of the earliest written legal documents, Hammurabi's code carried many laws pertaining to debt and credit, laws important enough to be chiseled into solid rock and displayed publicly. Credit and debt were not only part of an ancient institution of social and economic organization, but an integrated information system defining personal identity. As a measure of an individual's place within a given community, one' participation in the credit system was directly linked to the identity, status, location, and class of the borrower. Etymologically, the word credit comes from the Roman word for trust and referred specifically to the character of the individual. Credit was, arguably until recently, an institution linked directly to the physical, social, and moral components of the self. The informal system of risk management embedded in early credit networks acted as a hedge against the otherwise chaotic systems of money and barter. Relations of credit and debt in the ancient world were mapped onto various social networks that existed within or across a given, community including those relations of domination, exploitation, and oppression. Matters of credit and debt were considered embodied and embedded within the individual (debtor) and their specific capacities, thereby directly shaping the contingencies and life chances of everyday existence contingencies increasingly subject to the contractual exchange of goods through markets (see Williams (2004) for a contemporary analysis).

The institutionalization of credit, whether as oral or written promise, was an essential component in the development of contract law - an innovation most notably refined and passed down in the Western world from the Romans (Watson, 1984). At its conceptual origin, the contract expressed a promise made willingly by legally equal parties. This simple premise - cthe ability to enter into a contract with another in the free exchange of promises and enforced by law - would later become the basis of the sovereign subject of (neo)classical economics and the primary agent in market centered philosophies of social organization (Macpherson, 1964). This agent would appear in the liberal political theory of Rousseau and Locke, and the liberal economic theory of Smith and Riccardo, recognized sardonically as the "free worker" by Marx ${ }^{2}$. The contract would emerge out of a legal and political economic system supporting the rights of equal and autonomous individuals to enter freely into contracts with each other (thus allowing free trade). Contractual exchanges, whether for finished goods or labor, constitute "the microstructure of the market mechanisms" (Ruggles, 2005, p. 35).

The systems of credit that evolved alongside the various political economies of Western civilization represent a fundamental social relation that is both pre-capitalist and morally charged. As a fundamental social relation, credit, reputation and social status were inseparable in the ancient

\footnotetext{
${ }^{1}$ I use the term 'apparatus' to denote the central role of automation in the networking of various institutions supporting the infrastructure of the credit system.

${ }^{2}$ Countering the valorization of the free worker by political economists, Marx writes: "For the transformation of money into capital, therefore, the owner of money must find the free worker available on the commodity-market; and this worker must be free in the double sense that as a free individual he can dispose of his labor-power as his own commodity, and that, on the other hand, he has no other commodity for sale, i.e. he is rid of them, he is free of al the objects needed for the realization of his labor power" (Marx, 1976, p. 272).
} 
world because they always lead directly back to a specific relationship between individuals, and were linked socially through the debtor's oral promise to repay (Mann, 2002, p. 7). As one preeminent social mediator, the organization of credit reproduced dominant social relations within a given historical context. Thus the relationship between creditor and debtor can be considered an ancient ensemble of relations (Gramsci, 1971); that is, a fundamental social institution for codifying and reproducing systems of hierarchy, class, trust, and risk.

To understand the contemporary mediation of the creditor-debtor social relation in the advanced capitalist economies, those marked by hyper-consumerism and neoliberal policies, it is necessary to look to the financialization of the global economy over the last three decades (Dore, 2008). The financialization that facilitated globalization of production and increased the circulation of capital through information and communication technologies (ICTs), also expanded consumer demand and desire for unsustainable consumption habits secured through a concurrent expansion of credit access (Comor, 2008). In so doing, exponential demand for credit reinforced a concurrent demand for more detailed consumer profiles gleaned from expansive consumer databases and census data. The resulting informational commodities that were ultimately used to assess and secure the value of securitized consumer debt created an industry dedicated solely to the purchase and sale of personal information (Lace, 2005; Goodhart, 2008). Combined with vast amounts of data and sophisticated data-mining techniques, these privately controlled 'bodies of data' are more than just passive storage spaces; in the hands of private enterprises they became active sites of production. On the productive powers of databases, Zwick and Knott (2009) explain that, "By capturing consumer activities ubiquitously and in minute detail, databases become repositories of complex consumer lives by turning behavior into abstract aggregates of individualized and individualizing data points. Once consumption has been dematerialized and been made available as coded, standardized and manipulable data, there are no more limits to the construction of difference, to classification, and to social sorting" (Zwick \& Knott, 2009, p. 222). Through the immense accumulation of personal information, and using increasingly sophisticated data mining techniques, the credit apparatus therefore acts as a nodal point in the analysis of trust and risk, now inseparable from the expansion of the personal data economy (Lace, 2005). The extension of private property rights to personal information, and the exploitation of the potential value locked therein, constitutes one way in which the corporeal is superseded by the virtual through capitalist social relations. As Ruggles explains, these data shadows come to "speak to our transaction partners for us, and often...speak for us on topics selected by others, and without our knowledge or volition" (Ruggles, 2005, p. 11).

Arguably, the unfolding credit crisis therefore represents both an economic and an ontological contradiction within post-Fordist accumulation strategies. Economic because the expansion of credit suggests the ephemeral or fictitious nature of contemporary global capital, pitting the infinite accumulation of fiat money against the finite productive capacities of value creating labor. Ontological, because the current crisis evidences deep-seated contradictions in capitalist accumulation related to the disappearing body (Lyon, 2002) of the sovereign self from creditor-debtor relations - a process which creates the necessary abstractions that stand-in for the corporeal self. This disappearance begins first, through the expansion of credit financed consumer purchasing and the creation of highly detailed databases of personal information, and then through the commodification of the resulting debt as a securitized informational product. Commodification dissolves the sovereign and morally coherent subject into an amalgam of personalized, and proprietary information upon which a market value is affixed, much in the same way abstract labor emerged from the statistical data increasingly available to managers in the eighteenth and nineteenth centuries. The aforementioned abstractions therefore represent the substitution of data for flesh as a lever for controlling future-labor, as a financial risk management tool, and as an expanded site for the commodification of personal information (van Dijk, 2010).

\section{Social Relations, Abstraction, Crisis}

Though this paper is couched in the familiar Marxist argument - that systemic and deepening crises are endemic to capitalist accumulation - it adds nuance to this narrative in suggesting that the current crisis expresses a contradiction stemming not only from an accumulation strategy, but also from the 'real abstractions' (Toscano, 2008) produced at the intersection of corporeal and digital identities. As Toscano (2008) has recently suggested, capitalism is, "the culture of abstraction par excellence...[capitalism] is really driven, in many respects, by abstract entities, traversed by 
powers of abstraction" (p. 273). Toscano continues, paraphrasing Enzo Paci, "The fundamental character of capitalism...is revealed in the tendency to make abstract categories live as though they were concrete. Categories become subjects, or rather, even persons... The abstract, in capitalist society, functions concretely" (ibid, p. 273). These abstractions become "a force operative in the world" and are "truly caught up in the social whole, the social relation" (ibid, p. 275). In the money system, for example, abstractions and social relations are dialectically related in the constitution of the individual. Marx writes that the capitalist abstractions which appear to free individuals from, for example, the despotism of feudal authority (abstractions like money, wage-labor, and private property as well as the contemporary credit system), merely signals,

"[t]he dissolution of these relations into a general form; they are merely the elaboration and emergence of the general foundation of the relations of personal dependence. Here also individuals come into connection with one another only in determined ways. These objective dependency relations also appear, in antithesis to those of personal dependence...in such a way that individuals are now ruled by abstractions, whereas earlier they depended on one another. The abstraction, or idea, however, is nothing more than the theoretical expression of those material relations which are their lord and master" (Marx, 1973 p. 164).

It is, however, not simply the money system that acts in the reproduction of abstractions. The commodity form itself plays a primary role when it begins to colonize and reshape a variety of social relations. Toscano elaborates, "it is the social activity of abstraction, in its form as commodity exchange, that plays the pivotal role in the analysis of real abstraction" (Toscano, 2008, p. 281). Let me pursue this line of analysis for a moment.

Chief among the abstraction producing mechanisms is the credit apparatus - a confluence of highly integrated and networked institutions including credit rating agencies, consumer database companies, financial institutions, and government regulatory bodies - whose raison d'etre is to support the circulation and expansion of capital. In the North American context, the three big US credit-rating agencies (CRAs) Experian, TransUnion and Equifax are among the key institutional players of the credit apparatus. These companies, by their own admission, maintain files on almost all individuals who have ever applied for credit ${ }^{3}$. TransUnion alone processes roughly two billion pieces of credit data every month (TransUnion, 2010), and Experian and Equifax have a combined operating revenue of almost 7 billion USD as of 2009 (Equifax, 2010; Experian, 2010). ${ }^{4}$ As private corporations, they convert consumer demand for credit into increasingly sophisticated mechanisms for assessing borrowers for a variety of clients including financial institutions, government agencies, potential employers, and landlords. With a monopoly of knowledge regarding personal financial data, these CRAs control and profit from the ideal of a fully reliable, yet abstract representation, of potential borrowers.

One of the central problems of post-Fordist capitalism generally, and exemplified by the current credit crisis specifically, is the central part played by CRAs in employing digital technologies to manage risk in an effort to actually reign in the rapid circulation of capital. Yet in so doing the resulting digital abstractions take on a reality all their own; that is, they become 'real.' Credit as fiat currency (Betancourt, 2010), however, does not create new value, but only a temporal deferment based on claims made on a vague notion of future abstract labor. In using credit to approach circulation without circulation time (that is to speed up the circulation of capital through stimulation of unproductive end-consumption), value is ascribed by financial intermediaries like banks to those processes within the production of circulation itself; namely, informational commodities used in expanding credit (particularly those involved in risk management), which are now mistaken for capital in the sphere of circulation. The abstractions produced within the digitally mediated apparatus of the contemporary credit system are called into being by the needs of circulating capital - they lubricate the circuit of capital by allowing commodities to more quickly find consumers. As a means of actually producing the circulation of capital by allowing consumers to absorb the increasing mass

\footnotetext{
${ }^{3}$ Though based in the United States, these companies are expanding globally, taking their proprietary techniques, databases, and expertise to both developed and emerging credit markets.

${ }^{4}$ According to Equifax's 2009 annual report, "The data and intelligence we derive from our broad base of assets-200+ million U.S. credit files; $200+$ million records at The Work Number; $\$ 10$ trillion in consumer wealth data from IXI; the National Consumer Telecom \& Utilities Exchange (NCTUE); and the 26 million files of small business information-are unique and not replicable. As a result, we can offer more differentiated solutions to our customers" (Equifax, 2010, p. 6).
} 
and diversity of commodity production, abstractions within the circulation of credit appear as sources of value in-and-of themselves. Consider this lengthy, but surprisingly lucid, passage from the Grundrisse:

"Thus circulation time appears as time which does not determine the price; and the number of turnovers, in so far as it is determined by circulation time, appears not in such a way that capital brings in a new value-determining element, an element proper to it, sui generis, as distinct from labor; but rather as a limiting, negative principle. The necessary tendency of capital is therefore circulation without circulation time, and this tendency is the fundamental determinant of credit and of capital's credit contrivances. At the same time, credit is then also a form in which capital tries to posit itself as distinct from the individual capitals, or the individual capital [tries to posit] itself as capital as distinct from its quantitative barrier. But the highest result it achieves in this line is, on one side, fictitious capital; on the other side, credit only appears as a new element of concentration, of the destruction of capitals by individual, centralizing capitals. Circulation time is in one respect objectified in money. Attempt by credit to posit money as a merely formal moment; so that it mediates the formal transformation without itself being capital, i.e. value. This is one form, of circulation without circulation time. Money is itself a product of circulation. It will be shown how capital, in credit, creates new products of circulation. But if the striving of capital in one direction is circulation without circulation time, it strives in the other direction to give circulation time value, the value of production time, in the various organs which mediate the process of circulation time and of circulation; to posit them all as money, and, more broadly, as capital" (Marx, 1973, p. 659).

In the above passage, Marx explains that the credit system, by attempting to reduce circulation time actually creates the abstractions necessary to do so, while at the same time creating the fictitious basis for new money capital to emerge. The credit system literally calls these abstractions into being because its purpose is to facilitate the movement of capital in the sphere of circulation. In so doing, it appears to confer phantasmic value to the "various organs which mediate the process of circulation time"-in this case the expression of debt as a globally marketable commodity. It is, however, the process of commodification, as it is filtered through the proprietary control of consumer data, that packages personal financial information into a market good. In the search of ways to model, anticipate, and predict future risk, a whole range of financial institutions rely on credit profiles and ratings to model future behavior. Value ascribed to informational (in so far as debt is merely a social relation projected into the future) commodities of this sort exists in a perpetually unmoored and speculative state.

Arguably, the widespread financialization of the global economy is in part dialectically related to the development and implementation of digital technologies. Yet digital technologies are implicated in capitalism's deeper structural dependence on abstraction. "The digital is a symptom of a larger shift from considerations and valuations based in physical processes towards immaterial processes; hence, 'digital capitalism' refers to the transfer of this immateriality to the larger capitalist superstructure" (Betancourt, 2010). The quantitative and qualitative expansion of available commercial information about consumers engenders a dependence on complex technical and legal foundations, including those of proprietary rights holders, and automated contractual exchanges. As a result, Betancourt argues, digital capitalism highlights an "underlying structural logic" based in a semiotic system driving "its participants towards immaterial values" (Betancourt, 2010) and thus ever sophisticated abstractions. As a consequence,

"[R]elations between commodities - relative value - becomes a purely social relation that denies any basis in past labor: what it enables is a shift into rentier claims on future labor - as agent for putting production in motion... These claims against future labor substitute for the historical duality of social and tangible commodities. This transaction is rentier in nature: it suggests the elementary form of commodity value is not expressed through relationships between commodities of any type, but rather through the ability to exchange the currency for labor to be performed, (also known as debt)" (Betancourt, 2010).

The fusion of neoliberal financial policies (discussed later in detail) and digital technologies generates a crippling dependence insofar as global capitalism is "threatened with immanent collapse 
when the circulation of credit ceases" (ibid). The result is an accumulation of fiat money with claims on future labor that exceed labor's actual (material) capacity. Betancourt explains: "The result is a cycle where claims against future production expand until they encounter the limiting factor: the ability of labor to meet the title levied against its future production; this constraint is the scarcity of capital" (ibid).

Although the propensity of American consumers to take on debt for consumer durables is not new (Olney, 1991), loosening access to credit allowed the stabilization of demand in a period of declining wages. Thus hegemony for post-Fordist flexible accumulation strategies was built upon a democratization of credit in the 1980s and 1990s, providing access for greater swaths of the working and middle classes to once scarce financial resources (Taylor, 2002). In 2009 the credit apparatus of the United States produced 2.5 trillion USD in consumer debt, about 400 million USD of which would be securitized and dumped on international financial markets until new accounting rules required banks to reassign these securities to other financial categories (U.S. Federal Reserve, 2010). Easy access to credit acted as a stabilizing mechanism while a patchwork of neoliberal policies rolled back workers' wages and protections. Consumerism on the whole acted to channel all desire and affect into consumption of commodities; distractions of various kinds (video games, reality television, internet surfing) therefore counterbalanced social anxieties (see Comor, 2008). I now turn to a historically specific instance of the aforementioned processes of abstraction situated at the heart of consumer and financial capital and expressed in the American credit crisis.

\section{The Commodification of Debt Part 1: Rise of the Virtual Debt Factory}

In early 2007, capitalism's crisis prone tendencies challenged the integrity of its credit-based house of cards. It began simply enough with an inflated housing market spurred by the influx of foreign investment, lead by Chinese credit and recycled oil revenues from OPEC nations (Weissman, 2008). The inflated housing market had enabled many - particularly those with lower incomes and minorities - to expand their available credit pool because: a) there was more personal information available to assess potential borrowers, and b) they could mortgage the wealth thought to exist in their homes over a relatively long period of time in exchange for immediate access to financial resources. The bubble in the housing market spurred an entire industry of lenders seeking to cash in on consumers already awash in credit debt. The assumed resiliency of the housing market in the long term was to act as a stabilizing force balancing out short-term loans. This was the perception for many who gambled with their homes and reputations.

One of the most pernicious, and now infamous, outcomes of this climate was the rise and fall of a market in sub-prime mortgages; a relatively new financial sub-industry thriving on giving low income or otherwise risky borrowers loans with little to no indication of the long term capacity to repay (Schwartz and Bajaj, 2007). Sub-prime mortgages, which made up $20 \%$ of the mortgage market, usually carried "interest rates 2 or 3 per cent above conventional mortgages. But, under complicated formulas, which critics say can come close to fraud, they usually offer very low 'teaser' rates for a limited period" (Cornwell, 2007). Though the exploitative nature of this industry was first directed at riskier borrowers, even individuals with good credit began falling behind on loan payments, resulting in some borrowers seeing "payments jump 50 percent or more" while note being able to "sell their properties for as much as they owe" (Bajaj, 2008).

Beginning as early as 1977 , securitization enabled the commodification of debt by allowing mortgages to be "purchased from the originator of the loan, repackaged as bonds, sorted according to supposed risk, and certified by bond-rating agencies, thus allowing any number of investors to buy the bonds. Each player along the way took a cut, raising costs to borrowers" (Kuttner, 2007). As a result, securitization allowed sub-prime lenders to sell borrowers debts as long "as some investment bank could be found to buy the loan, convert it to a bond, and peddle it to someone else, the mortgage companies could still turn a profit" (ibid.). The massive breadth and depth of data available to credit rating agencies provided a final qualitative step in fusing debt with the commodity form by literally quantifying risk for global investors. This is also true for domestic buyers and sellers of debt as, "Credit card issuers, health care providers and cellphone companies now routinely sell debt that they deem uncollectible to debt buyers, who then either try to collect it themselves, turn it over to a collections law firm or sell it again" (Martin, 2010).

As a commodity on the international financial market, debts were sold to investors as sources for short-term profits. Seeking high yield investments, buyers of securitized mortgages did not really 
know the conditions under which debts were taken on. In the process of commodification, debts were emptied of all contextual information-the circumstances under which debts are formed and what promises were made. Buyers of these securitized debts were not specialists who understood the long-term implications of these investments, "but generalists who looked at these bonds as a way of earning higher yields" (Schwartz and Bajaj, 2007). Lenders thereby perpetuate a "moralhazard problem because they have no reason to care about their borrowers' creditworthiness so long as they can quickly pass the loan along to remote investors"' (Desmond, 2008). According to economist Paul Krugman:

"Underlying the glamorous new world of finance was the process of securitization. Loans no longer stayed with the lender. Instead, they were sold on to others, who sliced, diced and puréed individual debts to synthesize new assets. Sub-prime mortgages, credit card debts, car loans - all went into the financial system's juicer. Out the other end, supposedly, came sweet-tasting AAA investments" (Krugman 2009).

The manipulation of credit ratings to present the illusion of safe and secure investments was an important element leading to the crisis (Schwartz \& Bajaj, 2007). Moreover, this manipulation of credit information represents a subversion of the trust placed in the (neo)liberal subject whose stable identity and rational actions are essential to the smooth functioning of the free market. Instead, abstract systems comprised of vast quantities of personal data came to stand-in for the individualdistilled into a crude score said to capture the essence of an individual's identity.

With such complex and abstract systems comes the potential for manipulation. Desmond explains that instead of ruining individual credit scores, these systems were employed to raise such scores in the efforts to commodify and sell individual debt as lucrative investment opportunities. "Methods that work include opening new credit card accounts, paying down some debts or transferring balances among cards, and creating links with friends or relatives who have good credit, since associated profiles bear on a borrower's score" (Desmond, 2008).

A credit rating is a score assigned to an individual using a highly complex scoring program (for example, the Fair Isaac system used in the United States) that processes a range of information in assessing an individual's credit worthiness, i.e. their ability to pay debts off in a timely, and profitable way (Desmond, 2008). Scores range between 350 and 850 with 600 being the threshold between relatively risky and relatively safe borrowers. The higher the score, the more likely debts will be repaid. Turner (2003) writes that "[t]he development and implementation of sophisticated consumer credit scoring models is among the most important innovations made possible by the current full-file credit reporting system. Lenders use credit scoring models to allocate credit and manage risk on an on-going basis" (Turner, 2003, p. 35).

Similarly, the widespread availability of personal data, including information about credit habits, combined with complex geodemographic information facilitates the predatory lending that targets middle and lower income groups, specifically minorities desperate to live the American Dream. Citing a recent study, Cornwell states: "racial minorities are more likely to be given high-cost, subprime mortgages-in six major American cities, black borrowers were 3.8 times more likely than whites to receive a higher-cost home loan" (2007). A recent study has illustrated how the processes of financialization embedded in the growth of the credit apparatus have actually quadrupled the "wealth gap between white and African-American families" in part because they had "no assets at all to turn to in time of economic hardship"; a period during which "African-Americans owed at least $\$ 3,600$ USD, almost doubling their debt burden since 1984" (Shapiro et al., 2010, p. 1). The ability to target vulnerable groups with predatory lending schemes is largely related to the commercial availability of personal information-often built upon publicly funded agencies like the U.S. Census Bureau - creating geodemographic grids in which information like race and income can be overlaid and exploited (Goss, 1995). Gandy (2010) summarizes the implications: "The routine, but increasing investment of resources in the identification, classification and evaluation of people, places and things is meant to produce actionable intelligence or guidance about choices that have to be made. These choices often result in the reinforcement or exacerbation of inequality within society" (2010, p. 30).

The exploitation of these information systems for the purposes of profit has more recently evidenced a serious crisis at the heart of the crucial role of homeownership in the political economy of the United States. Homeownership and the provision of mortgages to low income and working 
class people has been an essential part of capitalist hegemony. It keeps them "concerned about protecting their equity by keeping steady jobs and not engaging in revolutionary activity" (Duncan quoted in Ford, 1988, p. 189). As Harvey notes bluntly, "a worker mortgaged up to the hilt is, for the most part, a pillar of social stability" (Harvey quoted in Ford, 1988, p. 189). The family, and its spatial fixity, is an important part of capitalist reproduction, and the stability of capitalism relies on the reproduction of labor, a task traditionally accomplished within the family home. The post-Fordist hegemony is thus threatened when "an estimated 1.5 million homeowners in the US face foreclosure this year" (Cornwell, 2007).

Analysts have noted, however, that the credit crunch following the bursting of the housing bubble has, in some instances, not stopped consumer borrowing but has instead exacerbated matters by placing greater emphasis on credit cards to supplement the evaporation of credit in other spheres (Gutierrez, 2008). As mortgages begin to evaporate, consumer debt and mortgage foreclosures are accelerating in part through a shifting dependence on higher interest credit cards. As of the first quarter in 2009. Americans still hold almost \$US 850 billion (US) in credit card debt alone, down slightly from a high of almost \$US 960 billion in 2008 (U.S. Federal Reserve, 2010). As Westrich and Weller note, credit card debt declined relative to income over the last several years due to the growth of home equity lines of credit and other mortgage based loans, but recent trends have reversed this decline and put more emphasis on credit card debt as consumers use these higher interest forms of payment simply to pay for day-to-day expenditures. "It would seem that tightening access to credit in the mortgage market forced families to look elsewhere to borrow money to pay for ever more costly necessities, such as health care, transportation, utilities, and food, in a weakening labor market" (Westrich \& Weller, 2008, p. 4). The substitution of mortgage debt by credit card debt may simply prolong the inevitable collapse of the neoliberal credit apparatus. In addition to higher interest rates, credit card debt "tends to carry substantially higher costs than other forms of credit due to a myriad of fees and confusing terms that determine what actions could cause the lender to raise rates" (ibid, p. 7).

What has happened in the course of the last several years has been an increasing dependence on easy/cheap credit that has, in turn, become dependent on more costly forms of credit; "credit card lenders can raise the rate for no reason at all" (ibid, p. 7). Interestingly, the amount of both credit card and mortgage-backed securities were "eerily" similar in 2007, each hovering around $\$ 900$ billion (ibid, p. 8). This is an indication both of the incredible growth in the commodification and sale of debt as an informational entity, but also of the crucial role these commodities played in stabilizing global financial markets. As consumer dependence shifts from home equity to plastic, credit card companies have started limiting consumer's credit lines based on changing purchasing habits. Using credit cards to pay for basics like health care and groceries is interpreted by credit card companies as a sign of impending defaults resulting in curbed access to credit (Dash, 2008).

The inability to break out of a dependence on credit signals a much deeper psycho-social dependence on a lifestyle that is beyond most people's income. The net result is an acceleration of consumer defaults, and an overall weakening of financial markets, forcing banks to write off considerable amounts of debt while at the same time condemning consumers to a life of perpetual indebtedness. Recent figures have demonstrated that home foreclosures are up in $75 \%$ of the metropolitan areas in the United States, with an estimated 3 million homes getting at least one foreclosure notice and banks expected to take over roughly 1 million mortgages (Adler, 2010).

\section{The Commodification of Debt Part 2: Neoliberalism and the Deregulation of Financial Markets}

In addition to the rise of securitization as a significant abstraction creating mechanism and therefore contributor to the global financial crisis, the seeds of the current crisis are clearly linked to the re-regulation of financial institutions according to neoliberal principles; namely, privatization, deregulation, and liberalisation. Though many of these policies were introduced during the Reagan era, the most important moments occurred during the Clinton years. Clinton, tacitly invoking Reagan, claimed that the "era of big government was over" and subsequently allowed the Republican Congress to repeal "a Depression-era law called Glass-Steagall, which kept banking and investment separate. Henceforth, banks could offer investment advice as well as loans - one-stop 


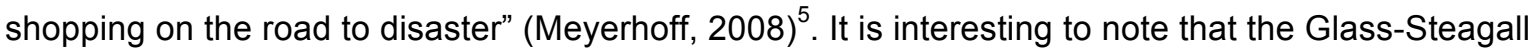
law was originally enacted "in response to speculation and manipulation of the markets by huge banking firms, which most liberal economists believed had brought on the crash of 1929. GlassSteagall imposed firewalls between commercial banking and investment banking, and between the banking, brokerage, and insurance industries" (Ridgeway, 2008).

With neoliberal ideology firmly grounded in both major American political parties, and with Newt Gingrich's Contract with America governing policy making, Congress enacted the Private Securities Litigation Reform Act, "making it far more difficult to prove securities fraud" (Meyerhoff, 2008). This piece of legislation laid the foundation for a spate of corporate fraud cases, including high profile scandals involving huge corporations like Enron, WorldCom, and Tyco, among others. "As a result, shareholders lost hundreds of billions of dollars from a wave of fraud unseen since the Roaring '20s - and maybe not even then" (Meyerhoff, 2008). These events were preceded by the savings and loans scandals of the 1980s, both sharing a similar source; the neoliberal "ideology of deregulation and the capture of public policy for private gain by the financial industry" (Kuttner, 2007).

Paul Krugman summarizes the deregulatory zeitgeist of the 1980s:

"After 1980, of course, a very different financial system emerged. In the deregulation-minded Reagan era, old-fashioned banking was increasingly replaced by wheeling and dealing on a grand scale. The new system was much bigger than the old regime: On the eve of the current crisis, finance and insurance accounted for 8 percent of G.D.P., more than twice their share in the 1960s. By early last year [2008], the Dow contained five financial companies - giants like A.I.G., Citigroup and Bank of America" (Krugman, 2009).

The current crisis was in many ways immanent in the very mechanisms that lead to stock market crash of 1929. As the conventional narrative goes, the only thing that saved financial institutions from total collapse this time was a massive injection of American taxpayer money (1.5 trillion USD) into financial markets by Federal Reserve chief Ben Bernanke. Moreover, the estimated cost to American taxpayers for the government's commitment to remedying the financial crisis is at 3.7 trillion USD (Lawder, 2010). Talbot (2008) explains: "Banks know that they are too big for the government to allow them to fail. The moral hazard that is created will be reflected in their continuing to take on high degrees of debt and financial leverage and invest in risky assets with no concern for the consequences". Not surprisingly, the recent state backed bailout of Bear Stearns, AIG, and Freddie and Fannie Mac suggest a predisposition for supporting commercial and corporate actors, and their executives and major shareholders rather than the real victims of the meltdown (Ridgeway, 2008).

The government bailout of financial companies is evidence of the need to sustain a highly integrated network of global capital flows that includes national banks from China and Japan to Sweden and the European Central Bank: this system is simply too big to fail (Goodman, 2008). To use a cold war turn of phrase - the global financial system is so many dominos kept in check by the disembedding of capitalist social relations from their material groundings through digital technologies and neoliberal policies of privatization, deregulation, and liberalization. Nordhaug provides a more direct assessment of the international forces at work:

"Disembedded capitalist credit relations are based on the commodification of debt as loans and receivables are converted into liquid negotiable commercial securities. Particularist longterm relations are minimized. The system favours 'exit-based' forms of credit in the form of securities, which along with liberalization of the domestic financial system and cross-border capital movements minimize formal or informal barriers to the selling of credit claims in anonymous markets" (Nordhaug, 2004, p. 10).

Some analysts have noted that the current crisis is simply a prelude to a much broader crises. "New and unforeseen strains on consumer liquidity will push more consumers into precarious credit positions and cause consumer credit losses to be far worse than what is currently estimated, even by the most draconian of investors" (Moyer, 2008). As a result, "banks will rein in lending in return, to the tune of $\$ 2$ trillion worth of available credit lines" (ibid.). In the future, prospective borrowers

\footnotetext{
${ }^{5}$ Lobbyists for banking and finance industries spent an estimated 400 million USD to overturn this law (Talbott, 2008).
} 
will increasingly face the "tyranny" of the credit score (Nocera, 2010) as more than $25 \%$ of consumer, about 44 million, "now have a credit score of 599 or below [where a credit score of 600 is an important threshold between good and bad credit risks], marking them as poor risks for lenders. It's unlikely they will be able to get credit cards, auto loans or mortgages under the tighter lending standards banks now use" (Connelly, 2010). In addition to having credit scores permanently destroyed, old debts might now live forever through the permanence of digital information, following an individual around indefinitely (Martin, 2010).

Meanwhile, under the American neoliberal ethos of the last several decades, the gap between the wealthiest $1 \%$ and everyone else has grown due primarily to the financial manipulation of Wall Street rapidly expanding the class of billionaires almost overnight (Sklar, 2007). "Wealth is being redistributed from poorer to richer. Between 1983 and 2004, the average wealth of the top 1 percent of households grew by 78 percent... The bottom 40 percent lost 59 percent" (Sklar, 2007). According to the Congressional Budget Office of the United States, "the gaps in after-tax income between the richest 1 percent of American and the middle and poorest fifths of the country more than tripled between 1979 and 2007" (quoted in Sherman \& Stone, 2010, p.1). Where the Fordist mode of accumulation offered a relative balance of power between capital and labor - resulting in the stagflation of the 1970s - neoliberalism offered a credit apparatus enabling the expansion of consumerism, and in particular, homeownership. Yet the provision of easy credit masks the more substantive reorganization of capitalist accumulation. While the United States still struggles to counter the neoliberal tide in financial regulation, particularly regulations pertaining to consumer protections, without a popular political movement the momentum inexorably moves towards an expropriation of the indebted, jobless, and destitute as the reconstituted precarious workforce of digital capitalism.

\section{The Power of Abstraction: Digital Capitalism and So-Called Primitive Accumulation}

"For Marx it becomes the task of capitalism's critic to track down and decipher in the present the violent marks of a primitive accumulation-the marks of a history one must suppose here and now" (Brown, 2009, p. 577).

In this section, I use the term 'primitive accumulation' to refer to the wholesale disenfranchisement, or 'accumulation by dispossession' (Harvey's (2003) corollary term), directed predominantly at working class and marginalized peoples in relatively developed capitalist economies - those who have lost houses, jobs, and access to vital financial resources in the continuous unraveling of the credit crisis. I do not claim to present a comprehensive analysis detailing of the various ways in which primitive accumulation represents a force in the world today, but I suggest that the increasing substitution of data for flesh now embedded in the credit system evinces a new form of violence implicit in digital capitalism. Jason Read explains that,

"Primitive accumulation serves as the name not only for an event but also for a process: the expropriation and legislation necessary to destroy other economic and social relations to make them productive for capital. Primitive accumulation is the process of the separation of labor form the means of production and reproduction of its existence. Thus primitive accumulation becomes not only a cause of the capitalist mode of production but also its effect (Read, 2003, p. 27).

Primitive accumulation suggests "a point of transition between violence and right...always situated with respect to a transformation of violence and the emergence of a new type of violence" (ibid, p. 28). Might not such new forms of violence lie dormant in the information networks, databases, and technologies entrusted to substitute data for flesh? The credit system is an opportune area of analysis in this regard for, as Marx reminds us, it is the credit system which generally "conceals one of the sources of primitive accumulation in this or that people" (Marx, 1976, p. 920).

Substantive changes in the relationship between debtors and creditors arguably signal an important preliminary step in marking the cyclical reorganization of capitalist accumulation. In the rise (and return) of primitive accumulation Marx "finds violence and bloodshed" premised on "expropriation, including usury, which quite literally tear the producers from their means of production, most 
importantly the land" (Read, 2003, p. 24). As Marx details in Capital, the relationship between creditors and debtors played an important role in the first waves of primitive accumulation that lead to the enclosures act-a necessary precondition for capitalist accumulation because it created a market for labor-power (Marx, 1976, p. 706).

Yet primitive accumulation does not refer to some specific pre-cursory moment in the genesis of western capitalism. In Marx's critique of capital, the concept of primitive accumulation plays a dual role. On the one hand, it points to the specific historical conditions leading to the rise of capitalism for example, the enclosures movement in Britain. On the other hand, primitive accumulation is a necessary component of capitalism's survival strategy, a coercive (and often violent) mechanism for consolidating the power of capital over public or communal interests. Harvey (2005) has pointed in this direction with his analysis of post-9/11 geopolitics, and their historical antecedents. Violent, international conflict, and the double-headed hydra of imperialism and colonialism are inseparable parts of contemporary capitalism. Internally, the subjugation of the dangerous classes exhibits both structural inequalities (for example, access to financial and social capital) and violent repression (when such access is withheld or taken away). Primitive accumulation names not only a historical event, but also a process;

"[T]he expropriation and legislation necessary to destroy other economic and social relations to make them productive for capital. Primitive accumulation is the process of the separation of labor from the means of production and reproduction of its existence. Thus primitive accumulation becomes not only a cause of the capitalist mode of production but also its effect" (Read, 2003, p. 27).

The mass production, and resulting commodification, of consumer debt is an important lever in the reconstitution of the labor force through the creditor - debtor relation. As such, primitive accumulation is also necessarily rooted in a specific moral tale referencing the relationship between creditor and debtor, which is later transformed into a relationship between capitalists and workers). By emphasizing the personal responsibility and moral failings of the debtors within this central myth, the social relations underlying the capitalist system are effectively naturalized. In the consumption-focused economic foundations of contemporary market economies, the indebted are now faced with a precarious and contradictory cultural milieu where debt is at once an everyday necessity (if only to 'keep up with the Joneses'), but also a personal failing. Awareness of this contradictory milieu is often dependent on the inevitable and often threatening beckon of the creditor or debt-collector, a tangible reminder of the structured asymmetries at the heart of financial capital. Indeed, the role of this morality tale is key to the production of subjectivities-both capitalists and workers-whose very way of life are premised on the structured inequalities masked by this myth. As Read explains "primitive accumulation posits a theory of the formation of the capitalist mode of production...The origin provides the present with a moral alibi, dividing the capitalist and the worker along the lines of the good and the bad" (Read, 2003, p. 21).

The relation of debtor and creditor (as a morality tale and a structural inequality) reflects a deeper class antagonism. Producing a somewhat parallel analysis to Nietzsche's (1996), Marx relates the capitalist morality tale to a kind of original sin, where the "diligent" are rewarded with the means to accumulate wealth while the "other lazy rascals" are "condemned to eat his bread in the sweat of his brow" having "nothing to sell except their own skins" (Marx, 1976, p. 873). Although this myth disguises the history of primitive accumulation and acts as a framework in which the sovereign subject/laborer is produced, it cannot be actualized without the material conditions constitutive of these intentions; the neoliberal credit apparatus is but one example of this materiality. The relationship between creditor and debtors has an important constitutive role, not only in laying the foundation for the rise of a capitalist class - and historically, as a binary opposition that defined rulers and ruled - but indeed, in the very constitution of what will become the working class as a structurally reinforced underclass.

Reconstituting the lines between the credit-worthy and credit-unworthy, as Sassen describes, will enable a "systemic deepening [in the] expansion of the operational space for advanced capitalism - it expels people both in the global South and in the North even as it incorporates spaces" (Sassen, 2010, p. 45). Where economies in the global South are subject to the "accelerated acquisition of millions of hectares of land by foreign investors - to grow food and extract water and minerals, all for the capital investing countries," Sassen notes that, 
"This also holds for such a radically different instance as the sub-prime mortgage crisis, a largely global North dynamic. I see the sub-prime mortgage as extending the domain for high finance but in a way that delinks the financial circuit from the actual material entity that is the house, and hence from the neighborhood, and from the people who got the mortgage. All of these materialities are excluded from this type of articulation with high-finance-which means that the devastated neighborhoods are expelled from what are, strictly speaking, also traditional circuits of capital" (ibid, p. 45).

Marx was emphatic about the nature of primitive accumulation by prefacing it with 'so-called' and including it in scare quotes. What can Marx's discussion tell us about the current credit crisis, about the social relations reproduced through the convergence of neoliberal and informational capital? First, it suggests that to understand nature of capitalist crises of accumulation one must identify the dominant social relations that it inheres in. Primitive accumulation allows Marx to make a very specific historical argument about the ways in which social relations are created and reproduced. This does not suggest that capitalist accumulation cannot exist alongside primitive accumulation, but that this analytic focus looks at social relations, particularly those of creditor and debtor, are differentially mediated. As a result, this change in mediation enables a reorganization of capital accumulation that stresses the disciplinary capabilities of the credit apparatus (in addition to its production of commodifiable debt).

Second, the credit crisis reveals an intractable contestation of time between capitalists and workers. It pits long-term perspectives embodied in the lifestyles of mortgage holders, small-scale farmers, and wage-laborers generally against the immediate concerns of global finance capital. Brown suggests that, in the concept of primitive accumulation lies a politics of time in which "Marx addresses a repression of time much like that which orients the notion of globalization-asglobalized: the positing of a certain circular condition that obscures the constitutive violence of capitalism's self-extension and hence the happening of time." (Brown, 2010, p. 576) Brown writes cryptically, "primitive accumulation unfolds historically outside capitalism, yet, at the same time, it persists at the heart of capitalism's continual maintaining and reproducing of itself" (ibid, p. 578).

The sub-prime mortgage crisis illustrates how consumer debts are commodified and placed on the international market for sale to investors seeking high yield investments. As a result, the sociological working and middle classes-those most susceptible to expanding debt and predatory lending - are driven further down the economic ladder; creating an even more desperate pool of prospective laborers willing to take on low paying service sector jobs. Indeed, the expanding population of debtors, dependents, and paupers created by means of the credit system acts as "the lever of capitalist accumulation" (Marx, 1976, p. 784). Under post-Fordist capitalism, the credit apparatus has played a central role in the constitution of a "disposable industrial army...for the changing needs of the self-expansion of capital" creating "a mass of human material always ready for exploitation" (ibid). As a contemporary lever of capitalist accumulation, the credit apparatus, and its various abstractions, are deployed to manage "the political problem of the control of living labor" (Read, 2003, p. 84).

Once acting as a stabilizing mechanism enhancing labor control during a period of diminishing power for workers, the credit apparatus, through the mass production of consumer debt, now challenges the capacity for the capitalist system to successfully secure surplus value from the expansion of mass consumption. Because capital cannot fully re-socialize individuals towards lifestyle changes conducive to limited consumption habits in the timely manner required by the stock market (perhaps because of the associated high-costs), the indebted masses are driven back towards purer forms of exploitation, such as unemployment, crime, pauperism, outright poverty, or simply a life condemned to low-paying service sector jobs. Taken together these set the stage for a return of primitive accumulation as the primary form of class antagonism within the global North, one virtually erasing the post-war gains of working and middle classes.

Barbara Ehrenreich and Kelly Kennedy have chronicled the physical and psychological violence done to individuals, neighborhoods, and entire cities, that has circulated around the most recent explosion of home foreclosures, which is perhaps the most clear example of primitive accumulation (Ehrenreich, 2008; Kennedy, 2008). Particularly disturbing is the fact that, "Suicide is becoming an increasingly popular response to debt" (Ehrenreich, 2008). This can be contrasted to the collective response to home foreclosures in the 1930s "when farmers and tenants used mob power -and 
sometimes firearms - to fight foreclosures and evictions" (Ehrenreich, 2008). The situation is dire, as Meyerhoff explains, "Interest rates on millions of mortgages are set - like time bombs - to accelerate in 2008. Defaults of $\$ 1$ trillion are predicted - affecting not only large institutions such as pension funds, hedge funds and universities but also countless average Americans" (Meyerhoff, 2008).

Taking the bomb metaphor one step further, Louis S. Barnes, a partner at a major banking firm, called such mortgages "neutron loans" because "they killed the people and left the houses" (quoted in Schwartz, 2007). Perhaps more disturbing, are recent examples of debt-ridden fathers killing themselves and their families to avoid the shame of bankruptcy and foreclosure (Buck et al., 2009; Kennedy, 2008). The rising cases of debt related murders and suicides are quickly rising, and with another record year of foreclosures and bankruptcies in the United States, 2009 may deliver an increasing trend of debt related violence (Ehrenreich, 2008). Some estimates put the number of bank owned houses in the United States at roughly 700,000 in April 2010 (Hagerty, 2010), with the number steadily increasing as the contagion from sub-prime moves into prime lenders, combined with structural and growing unemployment. One need only walk through the decimated neighborhoods of Detroit, Michigan to see the continued and violent effects of capitalist contradictions, as its residents struggle against the structural, legal, and disciplinary abstractions of primitive accumulation - abstractions decentered and dematerialized in the flows of a digitally mediated global capitalism. These symptoms evidence an important parallel between the global North and global South thereby demonstrating the interconnectedness of primitive accumulation in the age of global capital:

"The potential for global replication of the financial innovation that destroyed 15 million plus households in the US, therewith devastating whole neighborhoods is the systemic equivalent, albeit on a much smaller scale, of the global South countries devastated by an imposed debt and debt servicing regime which took priority over all other state expenditures (Sassen, 2010, p. 45).

To be clear, primitive accumulation might occur in three key respects: in the acquisition of property and wealth from working and middle classes through the manipulation of financial structures and institutions; the forceful creation of a permanent indebted under class forced to assume jobs at the lowest rung of the economic ladder, increasingly in the service sector; and related, by creating a database of information about debt available to commercial uses and exploitation to create a virtual debtors prison, with the possibility for further predatory practices and political manipulation in addition to the risks of identity theft and other security issues.

\section{Conclusion}

Broad changes in the relationship between creditor and debtors, specifically the mediation of this relationship by sophisticated ICTs contributing to the commodification of debt, have played a crucial role in conjuring up the crisis prone tendencies of capitalism in the $21^{\text {st }}$ century. It demonstrates both the continuity and novelty of contemporary capitalism. The ebb and flow between labor and capital is readily discerned in the history of Western capitalism as Marx has exhaustively demonstrated; our own historical moment is situated at the cusp of yet another point in capitalist reorganization. This time, however, the fulcrum of this reorganization rests on the flows of information that define the global credit system, shaping the individual life chances of billions of people.

What we can glean from a Marxist perspective is an understanding of the ways in which intractable contradictions constitute the basis of perpetual crises within a given regime of accumulation. In the contemporary case, the crisis stemming from credit markets evidences a particularly acute contradiction stemming from the substitutions of data for flesh, which contributes to the 'dialectical inversion' making the creation of detailed personal information into the basis for a debt producing industry. At the same time, the conditions by which the credit apparatus has colonized the consumptive habits of everyday people have also put in place the means for a kind of virtual debtor's prison. The dissolution of the sovereign individual in the information flows of digital capitalism presents an often antagonistic split between the embodied individual whose consciousness is conditioned by the erratic rhythms of consumerism (and the short-term thinking entailed therein), and the rational, stable, digital self, a self that increasingly comes to replace the flesh and blood individual. 
As this paper has argued, the credit apparatus offers a locus for understanding the interrelationship between capitalist expansion and the production of individuals conducive to this expansion: individuals for whom the willingness to take on more debt is as important a factor in capitalist reproduction as the production of 'free laborers' willing to sell their labor.

Issues of public debt at the national level which preoccupies so many pundits and would-be populists mirrors the more private and personal nature of the crisis. The combination of an international credit crisis, intense resource wars, free trade arrangements, and the fluidity of transnational capital, indicate the extent to which post-Fordist capitalism - through a combination of digital technologies and neoliberal policies - has been stretched to its limits. What lies ahead is a strategic choice on the part of governments regarding how to address the now structural dependency on commodified consumer debt. The Bush administration's bailout of financial industries in the fall of 2008 with virtually no accountability, policies largely continued by the Obama administration, provides a clear, yet disturbing example of how private capital profits from the production of public and personal debt. Seen in the context of the struggle between capitalists and workers, the string of bailouts witnessed in the American context offers a partial inoculation against future structural, and potentially progressive reforms-thereby providing ideological fodder for an increasingly vocal cadre of deficit hawks, neoliberal proponents, and conservative activists.

\section{References}

Adler, L. (2010). Foreclosures up in 75 Percent of Top U.S. Metro Areas. Reuters. Retrieved July 29, 2010 , from http://www.reuters.com/article/idUSN2910144320100729

Bajaj, V. (2008). Housing Lenders Fear Bigger Wave of Loan Defaults. The New York Times.

Betancourt, M. (2010). Immaterial Value and Scarcity in Digital Capitalism. CTHEORY, Theory

Beyond the Codes. Retrieved July 10, 2010, from http://www.ctheory.net/articles.aspx?id=652

Brown, T. (2009). The Time of Globalization: Rethinking Primitive Accumulation. Rethinking Marxism, $21(4), 571-584$.

Buck, B., Lloyd, J., \& Ebright, O. (2009). Social Murder-suicide Father Awash in Debt. NBC

News/Associated Press. Retrieved July 22, 2010, from http://www.nbclosangeles.com/news/local/BREAKING- NEWSBodies-Found-in-Wilmington-Home.html

Comor, E. (2008). Consumption and the Globalization Project: International Hegemony and the Annihilation of Time. New York: Palgrave Macmillian.

Connelly, E. (2010). More Americans' Credit Scores Sink to New Lows. Associated Press. Retrieved July 18, 2010, from http://finance.yahoo.com/news/More-Americans-credit-scores-apf490198280.html x=0\&sec=topStories\&pos=5\&asset $=\&$ ccode $=$

Cornwell, R. (2007). American Dream Ends in Property Market Crash. Independent/UK. Retrieved July 18, 2010, from www.independent.co.uk/news/world/americas/american-dream-ends-in-property-market-crash-443566.html

Dash, E. (2008). Banks Trimming Limits For Many on Credit Cards. New York Times. Retrieved July 20, 2010, from http://www.nytimes.com/2008/06/21/business/21credit.html

Desmond, M. (2008, June 6). Lipstick on a Pig. Forbes. Retrieved July 20, 2010, from www.forbes.com/bonds/2008/06/06/credit-optimizer-expert-markets-bonds-cx md markets46.html

Dore, R. (2008). Financialization of the Global Economy. Industrial and Corporate Change, 17(6), 1097-1112.

Dyer-Witheford, N. (1999). Cyber-Marx: Cycles and Circuits of Struggle in High-Technology Capitalism. Urbana: University of Illinois Press.

Ehrenreich, B. (2008). Suicide Spreads as One Solution to the Debt Crisis. Alternet. Retrieved July 20, 2010, from http://www.alternet.org/workplace/93077/

Equifax. (2010). Equifax 2009 Annual Report. Retrieved July 20, 2010, from http://www.equifax.com/investor center/

Experian. (2010). Experian 2009 Annual Report. Retrieved July 20, 2010, from http://www.experianplc.com/investorcentre/reports/investor-reports/2010.aspx

Fisher, E. (2010). Media and New Capitalism in the Digital Age: The Spirit of Networks. New York, NY: Palgrave Macmillan. Ford, J. (1988). The Indebted Society: Credit and Default in the 1980s. London; New York: Routledge.

Gandy, O. (2010). Engaging Rational Discrimination: Exploring Reasons for Placing Regulatory Constraints on Decision Support Systems. Ethics and Information Technology, 12(1), 29-42.

Goodhart, C. (2008). The Financial Economists Roundtable's Statement on Reforming the Role of SROs in the Securitisation Process. Vox. Retrieved July 23, 2010, from http://www.voxeu.org/index.php?q=node/2667

Goodman, P. (2008). Too Big to Fail? New York Times. Retrieved July 20, 2010, from http://www.nytimes.com/2008/07/20/weekinreview/20goodman.html

Goss, J. (1995). "We Know Who You Are and We Know Where You Live": The Instrumental Rationality of Geodemographic Systems. Economic Geography, 71(2), 171-198.

CC: Creative Commons License, 2010. 
Gramsci, A., Hoare, Q., \& Nowell-Smith, G. (1971). Selections From the Prison Notebooks of Antonio Gramsci. New York: International Publ.

Gutierrez, C. (2008). Consumer Credit: Going for Broke. Forbes. Retrieved July 21, 2010, http://www.forbes.com/markets/2008/05/07/productivity-labor-update-markets-econ-cx_cg_0507markets31.html

Hagerty, J. R. (2010). How Many Homes Do Banks Have Up Their Sleeves? The Wall Street Journal. Retrieved July 21, 2010, from http://blogs.wsj.com/developments/2010/03/19/how-many-homes-do-banks-have-up-their-sleeves/

Harvey, D. (1990). The Condition of Postmodernity: An Enquiry Into the Origins of Cultural Change. Cambridge, Mass.: Blackwell.

Harvey, D. (2003). The New Imperialism. Oxford; New York: Oxford University Press.

Harvey, D. (2005). A Brief History of Neoliberalism. Oxford: Oxford University Press.

Kennedy, K. (2008). Financial Crisis Suicide Numbers Mounting. Huffington Post. Retrieved July 18, 2010 , http://www.huffingtonpost.com/2008/10/14/financial-crisis-suicide n 134453.html?page=5

Krugman, P. (2009). The Market Mystique. New York Times.

Kuttner, R. (2007). What's Behind the Sub-Prime Disaster. The American Prospect. Retrieved July 23, 2010, from http://www.prospect.org/cs/articles?article=whats behind the sub-prime disaster

Lace, S., \& National Consumer Council (2005). The Glass Consumer: Life in a Surveillance Society. Bristol: Policy.

Lawder, D. (2010). Us Financial System Support up $\$ 700$ bln in Past Year - Watchdog. Reuters. Retrieved July 22, 2010, from http://www.reuters.com/article/idUSN2010140720100721

Lyon, D. (2002). Everyday Surveillance: Personal Data and Social Classification. Information, Communication \& Society, $5(2), 242-257$.

MacDonald, S. B., \& Gastmann, A. L. (2001). A History of Credit \& Power in the Western World. New Brunswick, N.J.; London: Transaction Publishers.

Macpherson, C. B. (1964). The Political Theory of Possessive Individualism: Hobbes to Locke. London; New York: Oxford University Press.

Mann, B. H. (2002). Republic of Debtors: Bankruptcy in the Age of American Independence. Cambridge, MA: Harvard University Press.

Martin, A. (2010, July 30). Old Debts That Won't Die. New York Times.

Marx, K. (1973). Grundrisse : Foundations of the Critique of Political Economy ([1st American ed.). New York: Random House.

Marx, K. (1976). Capital Volume 1: A Critique of Political Economy. Harmondsworth, Eng.: Penguin.

Meyerhoff, A. (2008). Financial Forces Run Amok. Los Angeles Times.

Moyer, L. (2008). The Next Credit Crisis. Forbes. Retrieved July 20, 2010, from www.forbes.com/wallstreet/2008/05/20/whitney-banks-credit-biz-wall-cx Im 0521banking.html

Nietzsche, F. W., \& Smith, D. (1996). On the Genealogy of Morals: A Polemic By Way of Clarification and Supplement to My Last Book, Beyond Good and Evil. New York: Oxford University Press.

Nocera, J. (2010). Credit Score is the Tyrant in Lending. New York Times. Retrieved July 24, 2010, from http://www.nytimes.com/2010/07/24/business/24nocera.html? $r=1 \& s c p=1 \& s q=t y r a n n y \% 20$ of $\% 20$ the $\% 20$ credit $\% 20$ sc ore\&st $=\mathrm{cse}$

Nordhaug, K. (2004). Disembedding and Re-Embedding East-Asian Capitalism. Paper presented at the Fifth Pan-European International Relations Conference, The Hague, Netherlands.

Olney, M. L. (1991). Buy Now, Pay Later: Advertising, Credit, and Consumer Durables in the 1920s. Chapel Hill: University of North Carolina Press.

Read, J. (2003). The Micro-Politics of Capital: Marx and the Prehistory of the Present. Albany: State University of New York Press.

Ridgeway, J. (2008). It's the Deregulation, Stupid. Mother Jones. Retrieved July 20, 2010, from www.motheriones.com/commentary/columns/2008/03/deregulation-economic-crisis.html

Ruggles, M. A. (2005). Automating Interaction: Formal and Informal Knowledge in the Digital Network Economy. Cresskill, N.J.: Hampton Press.

Sassen, S. (2010). A Savage Sorting of Winners and Losers: Contemporary Versions of Primitive Accumulation. Globalizations, 7(1), 23-50.

Schwartz, N., \& Bajaj, V., (2007). How Missed Signs Contributed to a Mortgage Meltdown. New York Times.

Shapiro, T. M., Meschede, T., \& Sullivan, L. (2010). The Racial Wealth Gap Increases Fourfold. Waltham, MA: Brandeis University, Institute on Assets and Social Policy.

Sherman, A., \& Stone, C. (2010). Income Gaps Between Rich and Everyone Else More Than Tripled in Last Three Decades, New Data Show. Washington, DC: Center on Budget and Policy Priorities.

Sklar, H. (2007). Billionaires Up, America Down. Common Dreams. Retrieved July 20, 2010, from http://www.commondreams.org/archive/2007/10/22/4734/ 
Talbott, J. (2008, July 5). When Will the Housing Crash End? Common Dreams. Retrieved July 20, 2010, from www.commondreams.org/archive/2008/07/05/10125

Taylor, A. (2002). Working Class Credit and Community Since 1918. Houndmills, Basingstoke, Hampshire, New York: Palgrave Macmillan

Toscano, A. (2008). The Open Secret of 'Real Abstraction'. Rethinking Marxism, 20(2), 273-287.

TransUnion. (2009). Transunion fast facts. Retrieved July 20, 2010, from http://newsroom.transunion.com/easyir/pkit.do?easyirid=DC2167C025A9EA04\&version=live\&pagesec=corporate

Turner, M. (2003). The Fair Credit Reporting Act: Access, Efficiency, and Opportunity. Washington, D.C.: Information Policy Institute and the U.S. Chamber of Commerce.

United States Federal Reserve (2010). Consumer Credit. United States Federal Reserve. Washington D.C. Retrieved July 21, 2010, from http://www.federalreserve.gov/releases/g19/Current/

Van Dijk, N. (2010). Property, Privacy and Personhood in a World of Ambient Intelligence. Ethics and Information Technology, 12(1), 57-69.

Virno, P. (2003). A Grammar of the Multitude: For an analysis of contemporary forms of life. Los Angeles: Semiotext(e).

Watson, A. (1984). The Evolution of Law: The Roman System of Contracts. Law and History Review, 2(1), 1-20.

Weissman, R. (2008). Deregulation and the Financial Crisis. Common Dreams. Retrieved July 20, 2010, from http://www.commondreams.org/archive/2008/01/22/6531

Westrich, T., \& Weller, C. (2008). House of Cards: Consumers Turn to Credit Cards Amid the Mortgage Crisis, Delaying Inevitable Defaults. Washington, DC: Center for American Progress.

Williams, B. (2004). Debt For Sale: A Social History of the Credit Trap. Philadelphia: University of Pennsylvania Press.

Zwick, D., \& Knott, J. D. (2009). Manufacturing Consumers: Database as a New Means of Production. Journal of Consumer Culture, 9(2), 221-247.

\section{About the Author}

\section{Vincent Manzerolle}

Vincent Manzerolle is a Media Studies doctoral candidate and lecturer in the Faculty of Information and Media Studies at the University of Western Ontario, London, Canada. His research interests center on consumption and information technologies, the history of information systems, and mobile media. His dissertation work focuses on the international growth of smartphones and the role these devices play in mediating work and leisure time. 